(ICVS), School of Health Sciences, University of Minho, ICVS/3B'S - PT Government Associate Laboratory; ' Gastroenterology, Hepatology and Nutrition Unit, Pediatric Department, Braga Hospital; ${ }^{P}$ Pediatric Department, Braga Hospital, Braga, Portugal

Background The ESPGHAN/ESPID acute gastroenteritis (AGE) recommendations management were published in 2009.

Aim Study these recommendations in a tertiary hospital ER during rotavirus (RV) season.

Material and Methods Retrospective, observational and analytical study, from January 1 to April 30, 2010, in younger than 18 years old, admitted at the ER with criteria for AGE $>3$ stools in the last 24 hours).

Results From the 13780 children admitted in ER, 770 had AGE (incidence $5.6 \%$ ). Were male $57.1 \%, 93.5 \%$ came without prior referral and $91.5 \%$ didn't take Oral Rehydration Solution (ORS). Had fever $34.2 \%, 68.7 \%$ vomit and $10.9 \%$ dehydration. At the ER, the ORS was administered in $62.1 \%$. Diagnostic tests were not performed in $63.8 \% ; 4.4 \%$ were admitted at the observations room; $0.3 \%$ at the pediatric department. Age was significantly associated with use of ORS (ORS: $42.84 \pm 45.16$ months vs "no ORS": $87.16 \pm 64.61, p<0,001)$. The ORS was prescribed to $68.2 \%$, "not recommended" drugs in 63 cases and more often in older children ("not recommended" $67.05 \pm 60.46$ vs "no medication": $49.60 \pm 49.33$ months, $p=0,038$ ). Blood analyses were performed in $6.4 \%$ and in children significantly older (85.57 $\pm 65.62 v s 51.89 \pm 54.49$ months, $p<0,001)$. Similar results were observed for the urine dipstick $(85.57 \pm 65.62 \mathrm{vs}$ $54.14 \pm 49.51, p=0,002)$, stool $(85.57 \pm 65.62 v s 28.16 \pm 38.50, p=0,008)$ and stool/blood (85.57 $\pm 65.62 v s 13.45 \pm 13.85, p<0,001)$. At discharge, diet changes were recommended in $37 \%$ children.

Conclusion AGE incidence was 5.6\%. Management was most based on ESPGHAN/ESPID's recommendations. There was still an inappropriate use of drugs and diet changes. The use of ORS before referral to the ER was rare.

\section{LACTOSE HYDROGEN BREATH TEST (LHBT) IN CHILDREN: IS IT A USEFUL TOOL?}

doi:10.1136/archdischild-2012-302724.0689

KM Upatissa, BF Rodrigues, H Patel, S Mahadevan-Bava. Paediatrics, Russells Hall Hospital, Dudley, UK

Children with lactose malabsorption can present with chronic diarrhoea, increased flatulence, abdominal pain or constipation. The simple solution is a trial of Lactose free diet (LFD).

Aim and method: Our aim is to assess the usefulness of LHBT for objective measure of LI and appropriate dietary advice. We retrospectively reviewed 36 children with symptoms of Lactose Intolerance (LI), who underwent LHBT attending the paediatric gastroenterology clinic at RHH from 2009-2011.

Results 36 children (20M:16F) (34 Caucasian) aged 2-17 years were identified. All baseline tests and Coeliac screen were negative. The presenting symptoms: diarrhoea (12), flatulence (14), abdominal pain (10) IBS (2) and constipation (12). 12/36(33\%) were positive (8/12 hydrogen load suggested LI and $4 / 12$ small bowel bacterial growth) LHBT. 5/8 with positive LI, showed marked improvement on LFD. Although 24/36 were negative LHBT, 5/24 started trial of LFD with $3 / 5$ success.

Conclusion LHBT is a simple non invasive and cost effective test that is useful in diagnosing LI in children. It gives objective evidence to parents to commence lactose free diet, thereby avoiding unnecessary omission of milk and dairy-products (19/36 potential cases in our study) that can have detrimental effects on calcium and vitamin $\mathrm{D}$ intake in children.
'V Ismaili-Jaha, ' $\mathrm{M}$ Shala, 'M Azemi, 'T Hoxha, 'M Avdiu, ${ }^{2} \mathrm{~S}$ Spahiu. 'Pediatric Gastroenterology; ' ${ }^{2}$ niversity Clinical Centre of Kosova, Pediatric Clinic, Prishtina, Kosovo

Material and methodology Authors have studied the seasonal distribution of the gastroenteritis caused by rotavirus. The study was prospective and was conducted at the Department of Pediatric Gastroenterology of the University Clinical Center of Kosova, during one year. Testing of the stool was performed using agglutination test with the sensitivity and specify of around $96 \%$.

Results Of 1011 children aged 0-5 years, hospitalized at the Department of Pediatric Gastroenterology due to gastroenteritis, 116 had rotavirus infection. At the admission all children were with diarrhea, $97.41 \%$ had vomiting and $43.96 \%$ had fewer. $70.7 \%$ of patients had moderate dehydration and $29.3 \%$ severe dehydration All patients in the study were intravenously rehydrated. All patients healed with no sequels. The seasonality of the disease was distinctive and had two peaks - first in late winter/early spring (January-16, February-9, March-9 and second in late summer/early autumn) August-11, September-20 and October-14

Conclusion Two peaks seasonality late winter/early spring and late summer/early autumn of the rotavirus infection reflects the difference in the wealth of the population in Kosova, with first peak in winter, similar to the one in the developed countries and the second peak in summer, similar to the one in non-developed countries.

\section{CLINICO-EPIDEMIOLOGICAL CHARACTERISTICS OF PEDIATRIC ESOPHAGITIS IN SOUTHERN IRAN: A SINGLE CENTER EXPERIENCE}

doi:10.1136/archdischild-2012-302724.0691

M Zahmatkeshan, K Najib, B Geramizadeh, E Fallahzadeh, M Haghighat, MH Imanieh. Shiraz University of Medical Sciences, Shiraz, Iran

Objectives To determine the clinico-epidemiological characteristics of pediatric esophagitis in southern Iran.

Methods A cross-sectional study was conducted during a 4-year period from 2005 to 2009 in Nemazee hospital, a tertiary healthcare center in Shiraz, southern Iran. We consecutively included all the pediatric patients ( $<18$ years) who underwent endoscopy in our center and had pathology-confirmed diagnosis of esophagitis. Data regarding the patients' demographic characteristics, comorbidities, and clinical findings were recorded using a questionnaire. All the patients underwent upper GI endoscopy and biopsy of the esophagus and the findings were recorded in the questionnaire.

Results We studied 125 children among whom there were 61 (48.8\%) girls and $64(51.2 \%)$ boys with mean age of $6.6 \pm 5.5$ years. Intractable vomiting was the prominent symptom in our series being reported by 75 (60\%) patients followed by fever in $35(28 \%)$. Erythema (33.6\%), esophageal ulcer (11.2\%), and whitish patch $(8.0 \%)$ were the most common endoscopic findings while reflux esophagitis $(32.8 \%)$, chronic $(6.4 \%)$ and acute esophagitis $(5.6 \%)$, and candida esophagitis (5.6\%) were the most common histological diagnoses. Just $1(0.8 \%)$ patient was diagnosed as having eosinophilic esophagitis, aspergillosis, and graft versus host disease.

Conclusion Reflux is the most common cause of esophagitis in the pediatric population of southern Iran. Despite previous reports the prevalence of eosinophilic esophagitis is far less than estimated while the prevalence of opportunistic infections is higher secondary to post liver transplantation immunosuppression.

\section{INCREASING THE FREQUENCY OF EOSINOPHILIC ESOPHAGITIS IN CHILDREN: IS IT REAL?}

